\title{
Neopterin, procalcitonin, clinical biochemistry, and hematology in calves with neonatal sepsis
}

\author{
Enes Akyüz ${ }^{1}$ (D) $\cdot$ Gürbüz Gökce ${ }^{1}$
}

Received: 18 December 2020 / Accepted: 23 May 2021 / Published online: 9 June 2021

(c) The Author(s), under exclusive licence to Springer Nature B.V. 2021

\begin{abstract}
This study aims to determine how neopterin, procalcitonin, biochemical and hematological parameters change during treatment of calves with neonatal sepsis. A total of 25 calves divided into two groups. Sepsis group was composed of 15 newborn calves aged 0-10 days which met neonatal sepsis criteria, but did not receive any treatment. Control group included 10 healthy calves aged 0-10 days. Clinical examinations (respiratory rate, rectal temperature, heart rate, capillary refill time, sucking reflex) were performed at certain times before ( 0 th $\mathrm{h}$ ) and during (12th, 24th, 48th, and 72th $\mathrm{h}$ ) the treatment. The blood was taken from the jugular vein from the sepsis group before (0th $\mathrm{h}$ ) and during the treatment (12th, 24th, 48th, and $72 \mathrm{nd} \mathrm{h}$ ) and once from the control group. Procalcitonin pretreatment ( 0 th $\mathrm{h})$ and control group concentrations were found as $178.08 \pm 2.4(\mathrm{pg} / \mathrm{mL})$ and $42.78 \pm 1.25(\mathrm{pg} / \mathrm{mL})$, respectively $(p<0.001)$. Neopterin pretreatment $(0$ th $\mathrm{h})$ and control group concentrations were determined as $14.44 \pm 0.30(\mathrm{ng} / \mathrm{mL})$ and $3.63 \pm 0.29(\mathrm{ng} / \mathrm{mL})$, respectively $(p<0.001)$. As a result, neopterin and procalcitonin concentration decreased along with the treatment, confirming the presence of sepsis in calves and suggesting that sepsis could be a prognostic indicator. Therefore, both procalcitonin and neopterin can be prognostic and diagnostic in calves with sepsis.
\end{abstract}

Keywords Calf $\cdot$ Neonatal $\cdot$ Neopterin $\cdot$ Procalcitonin $\cdot$ Sepsis

\section{Introduction}

Sepsis and diarrhea are diseases with high morbidity and mortality in neonatal period (up to the first 4 weeks after birth). Mortality rate can increase due to colostral transfer insufficiency (Aydogdu and Guzelbektes, 2018; Basoglu et al. 2018; Yildiz et al. 2018; Kirbas et al. 2019; Akyüz et al. 2019). Mortality rates can range from 15 to $30 \%$ during this period. Mortality is mainly caused by infectious diseases, diarrhea, respiratory system disorders, and especially sepsis. Sepsis is a process with complex etiology leading to multiple organ failure (Chatre et al. 2017; Basoglu et al. 2018). In neonatal period, calf diseases can be caused by a single factor, or can occur due to a combination of several factors (Erkiliç et al. 2019). Various factors play a role in the etiology of calf diarrhea, mainly including viral, bacterial, and protozoal factors (Ok et al. 2009). Diarrhea caused by

Enes Akyüz

enesakyuz_44@hotmail.com

1 Department of Internal Medicine, Faculty of Veterinary Medicine, Kafkas University, Kars, Turkey
Escherichia coli (E. coli), cryptosporidium, rotavirus, and coronavirus is more common in calves during the first four weeks of life (Lorenz et al. 2011). Serious complications caused by E.coli can lead to death (Constable, 2007; Akyüz et al. 2016). Infectious agents that cause diarrhea are usually taken orally. It takes an important place in unsuitable environmental conditions. Infectious agents can be taken through omphologen and air in addition to oral intake (Trefz et al. 2013). Symptoms of sepsis are decreased interest in environment, loss of appetite, and diarrhea. Some of the other clinical findings of sepsis are poor sucking reflex, depression, lethargy, low body temperature, changes in respiratory rate, changes in capillary refill time (CRT), and dehydration (House et al. 2015; Bonelli et al. 2018). Systemic inflammatory response syndrome (SIRS) and sepsis criteria in neonatal calves are rectal temperature $\left[\left({ }^{\circ} \mathrm{C}\right)>39.5,<37\right]$, heart rate $[($ pulse $/ \mathrm{min})>160,<100]$, respiratory rate $[(\mathrm{min})>45]$, $\mathrm{SpO} 2[(\%)<90]$, mean blood pressure $[(\mathrm{mmHg})<65]$, total leukocyte $\left[\left(\times 10^{3} / \mu \mathrm{L}\right)>12,000,<4000\right]$ (Fecteau et al. 1997, 2009; Sen and Constable, 2013; Y1ld1z et al. 2018; Beydilli and Gökçe, 2019). A treatment protocol including oral and parenteral antibiotics, liquid-electrolyte, sodium bicarbonate, 
non-steroid anti-inflammatory, and vitamins A, B, C, D, and $\mathrm{E}$ is administered in calves with neonatal sepsis (Çitil and Gökçe, 2013). In addition, deteriorated acid base and electrolyte balance should be regulated in these calves. Preventing formative sepsis constitutes main lines of the treatment (Sen and Constable, 2013). Sepsis is a complex process. Therefore, it has led studies to focus on this direction. Some biomarkers vary particularly in diagnosing diseases, providing important information in terms of prognosis. The importance of using biomarkers to diagnose sepsis is increasing day by day in both medicine and veterinary medicine (Moore et al. 2007; Maden and Köse, 2013). Procalcitonin, acts as the precursor of calcitonin hormone, is synthesized by $\mathrm{C}$ cells of the thyroid gland, and exists in the blood at low levels under normal conditions. The regulation and synthesis of procalcitonin are controlled by calcitonin gene 1 (CALC1). Procalcitonin is used in the prognosis and diagnosis of sepsis and septic shock (Matur et al. 2017). If procalcitonin concentration is below $0.2 \mathrm{ng} / \mathrm{mL}$, it indicates no sepsis or systemic inflammation; however, it is defined as sepsis if the concentration is between 2 and $10 \mathrm{ng} / \mathrm{mL}$, and severe sepsis when the concentration is above $10 \mathrm{ng} / \mathrm{mL}$. In addition, the greater the procalcitonin concentration, the greater the mortality rates (Chivate et al. 2016; Matur et al. 2017). Neopterin, another important biomarker, is a metabolic compound of guanosine triphosphate, which chemically belongs to pteridine group. It is released from macrophages and dendritic cells stimulated by cytokines (Michalak et al. 2017; Pergialiotis et al. 2018). Neopterin also increases in viral diseases. It can also be used as a clinical indicator in inflammatory and gram-negative bacterial sources (KozłowskaMurawska and Obuchowicz, 2008). Neopterin increases in SIRS lower than in septic shock. Therefore, neopterin may be important in differentiating SIRS from sepsis. In fact, the importance of neopterin in prognosis of sepsis is beneficial in terms of showing whether the living organism has an actual sepsis (Sönmezer and Tülek, 2015). This study aims to evaluate both how neopterin, procalcitonin and some serum biochemical and hematological parameters change during treatment of calves diagnosed with sepsis and their prognostic significance.

\section{Material and methods}

This study was conducted after the approval of the Kafkas University Local Ethics Committee (KAUHADYEK/2018-002), Kars, Turkey.

\section{Animals}

The animal material consisted of a total of 25 calves in two groups. Sepsis group $(n=15)$ was composed of newborn calves aged 0-10 days which met neonatal sepsis criteria but did not receive any treatment. Control group $(n=10)$ included healthy calves aged 0-10 days in the Veterinary Medicine, Education, Research and Application Farm, Kars Turkey.

\section{Procedures}

A commercial rapid test kit (BoviD-5 Ag Test Kit ${ }^{\circledR}$, Bionote Inc., Korea) was used to detect etiological factors in feces of calves with neonatal sepsis. Calves with symptoms of depression, diarrhea, low/lack of sucking reflex, dehydration, and constant urge to lie down were examined and then evaluated in accordance with sepsis criteria. Accordingly, the SIRS criteria for neonatal calves were given below (Fecteau et al. 1997, 2009; Yıldız et al. 2018);

- Body temperature $>39.5{ }^{\circ} \mathrm{C}$ or $<37^{\circ} \mathrm{C}$

- Pulse rate per minute $<100$ or $>160$

- Respiratory rate per minute $>45$

- Leukocyte count $>12 \times 10^{3} / \mu \mathrm{L}$ or $<4 \times 10^{3} / \mu \mathrm{L}$

Calves having at least two of the specified criteria, which were assessed as SIRS, and with the presence or suspicion of infection, were evaluated to have sepsis, and therefore included in the study. Throughout the study, clinical examinations (respiratory rate, rectal temperature, heart rate, capillary refill time, sucking reflex) of the calves were performed at certain times before (0th h) and during (12th, 24th, 48th, and 72th $\mathrm{h}$ ) the treatment. Blood samples were taken from the jugular vein with a holder and sterile needle tips (Vacuette ${ }^{\circledR}$, Greiner Bio-One $\mathrm{GmbH}$, Austria) from the sepsis group before (0th $h$ ) and during the treatment (12th, 24th, 48th, and 72nd h) and once from the control group. The blood was collected in gel-containing vacuum tubes (BD Vacutainer $\left.{ }^{\circledR}, \mathrm{BD}, \mathrm{UK}\right)$ for biochemical measurements and $\mathrm{K}_{2}$ EDTA-containing tubes for hematological measurements (BD Vacutainer ${ }^{\circledR}, \mathrm{BD}, \mathrm{UK}$ ). After the blood samples collected in vacuum tubes were kept at room temperature for approximately an hour, serum samples were obtained by centrifuging the blood samples for $10 \mathrm{~min}$ at $3000 \mathrm{rpm}$ (Hettich Rotina 380R®, Hettich, Germany). Serum biochemical and hematological parameters were measured daily. The serum samples to be used for neopterin and procalcitonin measurements were stored at $-20{ }^{\circ} \mathrm{C}$ until analysis. Alanine aminotransferase (ALT), aspartate aminotransferase (AST), gamma-glutamyl transferase (GGT), alkaline phosphatase (ALP), glucose, creatinine, urea, albumin, and creatine kinase (CK) were measured by using a fully automated biochemistry device (Mindray BS120®, Mindray Medical Technology Istanbul, Turkey). The total leukocyte count $\left(\mathrm{WBC} \times 10^{3} / \mu \mathrm{L}\right)$ was determined using a complete blood count device (VG-MS4e®, Melet Schloesing, 
France). Serum procalcitonin and neopterin concentrations were determined using commercial bovine-specific ELISA (enzyme-linked immunosorbent assay) kits (Bovine neopterin ELISA kit ${ }^{\circledR}$, Cusabio, China; Bovine procalcitonin ELISA kit ${ }^{\circledR}$, Cusabio, China). ELISA tests were performed as recommended by the manufacturer and the optical density was measured at a wavelength of $450 \mathrm{~nm}$ by a microplate reader (Epoch®, Biotek, USA). Fluid therapy was applied to calves with sepsis according to the severity of dehydration. For this purpose, the calves were intravenously administered $0.9 \% \mathrm{NaCl}(\mathrm{PVC} \circledast, 1000 \mathrm{~mL}$ Eczacibaşı Baxter, Istanbul, Turkey), $1.3 \% \mathrm{NaHCO}_{3}$ (Bikarvil®, Vilsan, Ankara, Turkey), and 5\% dextrose (Polifleks ${ }^{\circledR}$, Polifarma, Tekirdağ, Turkey). Enrofloxacin (Baytril \%10®, Bayer, Germany) was intramuscularly administered at a dose of $2.5-5 \mathrm{mg} / \mathrm{kg}$ for 5 days to control the infection. Neomycin sulfate and bismuth subcarbonate powder containing (Cesamolin ${ }^{\circledR}$, Topkim, Turkey) were given orally at a dose of $10-20 \mathrm{mg} / \mathrm{kg}$ for 3 days purposes intestinal antibacterial. For vitamin supplementation, the calves were also orally administered vitamin B complex (Berovit B12®, Ceva, Australia) in a practical dose of $8-10 \mathrm{~mL} /$ calf for 5 days, vitamin $\mathrm{C}$ (Maxivit-C®, Bavette, Turkey) at a dose of 4-6 mg/kg for 3 days, and vita$\min \mathrm{A}, \mathrm{D}_{3}, \mathrm{E}$ at a single subcutaneous dose of $1 \mathrm{~mL} / 50 \mathrm{~kg}$
(Ademin ${ }^{\circledR}$, Ceva, Australia). For mineral supplementation, they were subcutaneously administered a solution of $\mathrm{Ca}$, $\mathrm{P}$, and $\mathrm{Mg}$ (Kalsimin ${ }^{\circledR}$, Vilsan, Germany) at a single dose of $10 \mathrm{~mL} / 50 \mathrm{~kg}$. The calves were also administered nonsteroidal anti-inflammatory solution (Bavet Meloxicam ${ }^{\circledR}$, Bavet, Turkey) at a single dose of $4-6 \mathrm{mg} / \mathrm{kg}$. Data were analyzed using the SPSS ${ }^{\circledR}$ (SPSS 18.0, Chicago, IL, USA) software program. The Shapiro-Wilk test was used to evaluate the normality for groups (sepsis and control). As the data showed normal distribution, the groups were compared with parametric tests. One-way ANOVA and Tukey HSD post hoc test were used to assess the statistical differences between sepsis and control groups. Pearson correlation coefficients were calculated to define the correlation between variables. The results were presented using mean \pm standard error (SEM). A $p$ value less than 0.05 was considered statistically significant.

\section{Results}

Table 1 presents some serum biochemical parameters and clinical findings of calves. Sepsis group had significantly higher respiratory rate, heart rate, and capillary refill time

Table 1 Present serum biochemical parameters and clinical findings of calves included in the study

\begin{tabular}{|c|c|c|c|c|c|c|c|}
\hline \multirow[t]{2}{*}{ Parameter } & \multicolumn{5}{|l|}{ Hours } & \multirow[t]{2}{*}{ Control } & \multirow[t]{2}{*}{$p$ value } \\
\hline & $0 *$ & 12 & 24 & 48 & 72 & & \\
\hline $\begin{array}{l}\text { Rectal temperature } \\
\left({ }^{\circ} \mathrm{C}\right)\end{array}$ & $38.07 \pm 0.43$ & $38.18 \pm 0.16$ & $38.31 \pm 0.11$ & $38.29 \pm 0.15$ & $38.39 \pm 0.09$ & $38.52 \pm 0.06$ & 0.840 \\
\hline Breaths/min & $52.35 \pm 4.53^{\mathrm{c}}$ & $43.20 \pm 3.12^{\mathrm{bc}}$ & $37.20 \pm 1.46^{\mathrm{ab}}$ & $40.13 \pm 2.68^{\mathrm{abc}}$ & $34.57 \pm 1.18^{\mathrm{ab}}$ & $28.60 \pm 0.90^{\mathrm{a}}$ & $<0.001$ \\
\hline Heart beats/min & $135.18 \pm 12.57^{\mathrm{c}}$ & $120.80 \pm 6.30^{\mathrm{bc}}$ & $100.60 \pm 4.55^{\mathrm{ab}}$ & $99.33 \pm 4.87^{\mathrm{ab}}$ & $97.14 \pm 4.82^{\mathrm{ab}}$ & $85.20 \pm 2.43^{\mathrm{a}}$ & $<0.001$ \\
\hline Capillary refill time/s & $3.41 \pm 0.23^{b}$ & $1.97 \pm 0.06^{\mathrm{a}}$ & $1.83 \pm 0.17^{\mathrm{a}}$ & $1.73 \pm 0.24^{\mathrm{a}}$ & $1.46 \pm 0.04^{\mathrm{a}}$ & $1.50 \pm 0.01^{\mathrm{a}}$ & $<0.001$ \\
\hline $\begin{array}{l}\text { Total leukocytes count } \\
\left(\times 10^{3} / \mu \mathrm{L}\right)\end{array}$ & $9.62 \pm 2.04$ & $8.49 \pm 1.05$ & $9.86 \pm 1.19$ & $8.65 \pm 0.89$ & $9.65 \pm 1.22$ & $7.56 \pm 0.36$ & 0.865 \\
\hline $\begin{array}{l}\text { Alanine aminotransferase } \\
\text { (IU/L) }\end{array}$ & $15.12 \pm 2.70^{\mathrm{ab}}$ & $17.50 \pm 3.00^{\mathrm{ab}}$ & $22.05 \pm 3.26^{\mathrm{ab}}$ & $26.52 \pm 3.77^{b}$ & $24.78 \pm 3.14^{b}$ & $11.00 \pm 1.57^{\mathrm{a}}$ & 0.008 \\
\hline $\begin{array}{l}\text { Aspartate aminotransferase } \\
\text { (IU/L) }\end{array}$ & $94.79 \pm 1.69^{\mathrm{b}}$ & $68.35 \pm 8.77^{\mathrm{ab}}$ & $73.49 \pm 8.13^{\mathrm{ab}}$ & $73.63 \pm 6.46^{\mathrm{ab}}$ & $69.91 \pm 5.72^{\mathrm{ab}}$ & $64.04 \pm 9.71^{\mathrm{a}}$ & 0.029 \\
\hline $\begin{array}{l}\text { Gamma-glutamyl } \\
\text { transferase (IU/L) }\end{array}$ & $462.49 \pm 43.93^{c}$ & $409.89 \pm 56.96^{\mathrm{bc}}$ & $313.81 \pm 39.16^{\mathrm{abc}}$ & $249.38 \pm 23.71^{\mathrm{ab}}$ & $221.16 \pm 25.09^{\mathrm{a}}$ & $332.98 \pm 19.19^{\mathrm{abc}}$ & $<0.001$ \\
\hline $\begin{array}{l}\text { Alkaline phosphatase } \\
\text { (IU/L) }\end{array}$ & $218.33 \pm 18.71^{b}$ & $182.95 \pm 12.04^{\mathrm{ab}}$ & $179.48 \pm 9.91^{\mathrm{ab}}$ & $179.51 \pm 11.26^{\mathrm{ab}}$ & $172.27 \pm 11.37^{\mathrm{ab}}$ & $145.66 \pm 11.37^{\mathrm{a}}$ & 0.020 \\
\hline Glucose (mg/dL) & $76.19 \pm 5.29^{\mathrm{a}}$ & $113.88 \pm 9.37^{\mathrm{b}}$ & $98.78 \pm 5.33^{\mathrm{ab}}$ & $97.93 \pm 5.74^{\mathrm{ab}}$ & $94.42 \pm 3.90^{\mathrm{ab}}$ & $111.59 \pm 4.23^{b}$ & $<0.001$ \\
\hline Creatine (mg/dL) & $4.55 \pm 0.50^{\mathrm{b}}$ & $2.18 \pm 0.20^{\mathrm{a}}$ & $2.10 \pm 0.10^{\mathrm{a}}$ & $2.07 \pm 0.09^{\mathrm{a}}$ & $2.06 \pm 0.13^{\mathrm{a}}$ & $1.68 \pm 0.10^{\mathrm{a}}$ & $<0.001$ \\
\hline Urea (mg/dL) & $58.36 \pm 4.36^{\mathrm{b}}$ & $44.36 \pm 3.73^{b}$ & $50.64 \pm 4.84^{b}$ & $47.12 \pm 5.71^{b}$ & $46.47 \pm 4.53^{b}$ & $23.81 \pm 2.65^{\mathrm{a}}$ & $<0.001$ \\
\hline Albumin (g/dL) & $2.36 \pm 0.13^{\mathrm{a}}$ & $2.70 \pm 0.18^{\mathrm{ab}}$ & $2.93 \pm 0.13^{\mathrm{ab}}$ & $2.95 \pm 0.16^{\mathrm{ab}}$ & $2.96 \pm 0.14^{\mathrm{ab}}$ & $3.09 \pm 0.12^{\mathrm{b}}$ & 0.007 \\
\hline Creatine kinase (IU/L) & $383.58 \pm 68.11^{\mathrm{b}}$ & $360.75 \pm 70.96^{\mathrm{b}}$ & $414.69 \pm 48.00^{\mathrm{b}}$ & $358.89 \pm 57.93^{\mathrm{b}}$ & $197.86 \pm 35.08^{\mathrm{ab}}$ & $66.49 \pm 3.25^{\mathrm{a}}$ & $<0.001$ \\
\hline Procalcitonin (pg/mL) & $178.08 \pm 2.43^{\mathrm{d}}$ & $130.97 \pm 3.35^{\mathrm{c}}$ & $76.76 \pm 5.81^{b}$ & $65.31 \pm 8.40^{\mathrm{b}}$ & $42.56 \pm 0.79^{\mathrm{a}}$ & $42.78 \pm 1.25^{\mathrm{a}}$ & $<0.001$ \\
\hline Neopterin (ng/mL) & $14.44 \pm 0.30^{\mathrm{e}}$ & $12.62 \pm 0.26^{\mathrm{d}}$ & $8.29 \pm 0.34^{c}$ & $6.67 \pm 0.62^{\mathrm{b}}$ & $3.98 \pm 0.12^{\mathrm{a}}$ & $3.63 \pm 0.29^{\mathrm{a}}$ & $<0.001$ \\
\hline
\end{tabular}

${ }^{\mathrm{a}-\mathrm{e}}$ The mean concentrations with different letters in the same line represent the difference between patient and control groups by hour $(p<0.05)$. *Before treatment 
than those in the control group $(p<0.05)$. At the end of the treatment, these concentrations of sepsis group have reached at the levels of calves in the control group. There was no statistically significant difference between the sepsis and control group in terms of both body temperature $(p>0.05)$ and WBC $(p>0.05)$. Among 15 calves with sepsis, four had leukopenia and five had leukocytosis. However, the sepsis group had higher WBC than the control group, which was fluctuated during the treatment. Sepsis group had significantly higher ALT, AST, GGT, ALP, creatinine, urea, and CK concentrations than calves in the control group $(p<0.05)$. In addition, sepsis group had significantly lower pre-treatment serum glucose and albumin levels than those in the control group $(p<0.05)$. Calves in the sepsis group had higher neopterin and procalcitonin levels than those in the control group, and at 0 th $\mathrm{h}$ than at other hours (12th, 24th, 48th, and 72th h) of the treatment. Neopterin and procalcitonin in the sepsis group decreased during the treatment, and approached to the concentration of the control group. There was a statistically significant difference between the neopterin and procalcitonin concentration of sepsis and control groups (Table 1, Fig. 1, and Fig. 2). There was a statistically significant difference between the procalcitonin levels of sepsis and control groups, except the concentration measured at the 72th $\mathrm{h}$ of the treatment ( $p<0.05$, Fig. 1). Similarly, there was a statistically significant difference between the neopterin levels of sepsis and control groups, except the concentration measured at the 72 th $\mathrm{h}$ of the treatment $(p<0.05$, Fig. 2). The correlations of procalcitonin and neopterin with all parameters in the study are presented in Table 2. Significant positive correlation was determined especially between neopterin and procalcitonin. Physical examination findings showed a positive correlation between neopterin and procalcitonin with pulse per minute and respiratory rate. While similarly significant positive correlation was found in creatinine, significant negative correlation was determined in albumin (Table 2). No statistically significant result was found in the evaluation of neopterin and procalcitonin according to etiological agents $(p>0.05$, Table 3$)$.

\section{Discussion}

Sepsis develops more frequently in the first few days and a few hours after birth. Some clinical findings may appear due to development of sepsis. These clinical findings such as depression, diarrhea, inactivity, dehydration, increase in respiratory and heart rates, constant urge to sleep, drowsiness, and increase or decrease in body temperature vary according to the severity of the disease (Aldridge et al. 1993; Fecteau et al. 1997; Çitil and Gökçe, 2013). Similarly, this study observed clinical findings including depression, diarrhea, constant urge to sleep, dehydration and increased respiratory rate, and decreased/lack of sucking reflexes in some calves with sepsis, hyperthermia in some cases, and hypothermia in some other cases. Although the etiological factors and reasons greatly differ in calf sepsis, bacteria, viruses, and stress factors generally play a role in this disease. Among these factors, bacteria are the most common cause of sepsis. In particular, E. coli is the most commonly found bacteria in patients with sepsis, followed by klebsiella, salmonella, other gram-negative bacteria, and gram-positive bacteria. Among viruses, rotavirus and coronavirus most frequent cause of sepsis (Çitil and Gökçe, 2013). Similarly, in this study, E. coli, rotavirus, or coronavirus has been found alone in most of the cases, but in one case, both rotavirus and coronavirus found together. Unfavorable environmental conditions, inadequate hygienic protection, and insufficient colostrum play an important role in the development of sepsis (Tyler et al. 1999; Çitil and Gökçe, 2013). In consistent with those in the literature, this study was determined that the calves were
Fig. 1 The procalcitonin concentrations of the group with sepsis measured at different times and the procalcitonin concentration of the control group. $\mathrm{a}-\mathrm{d}$ indicates the statistical differences between the groups $(p<0.05)$

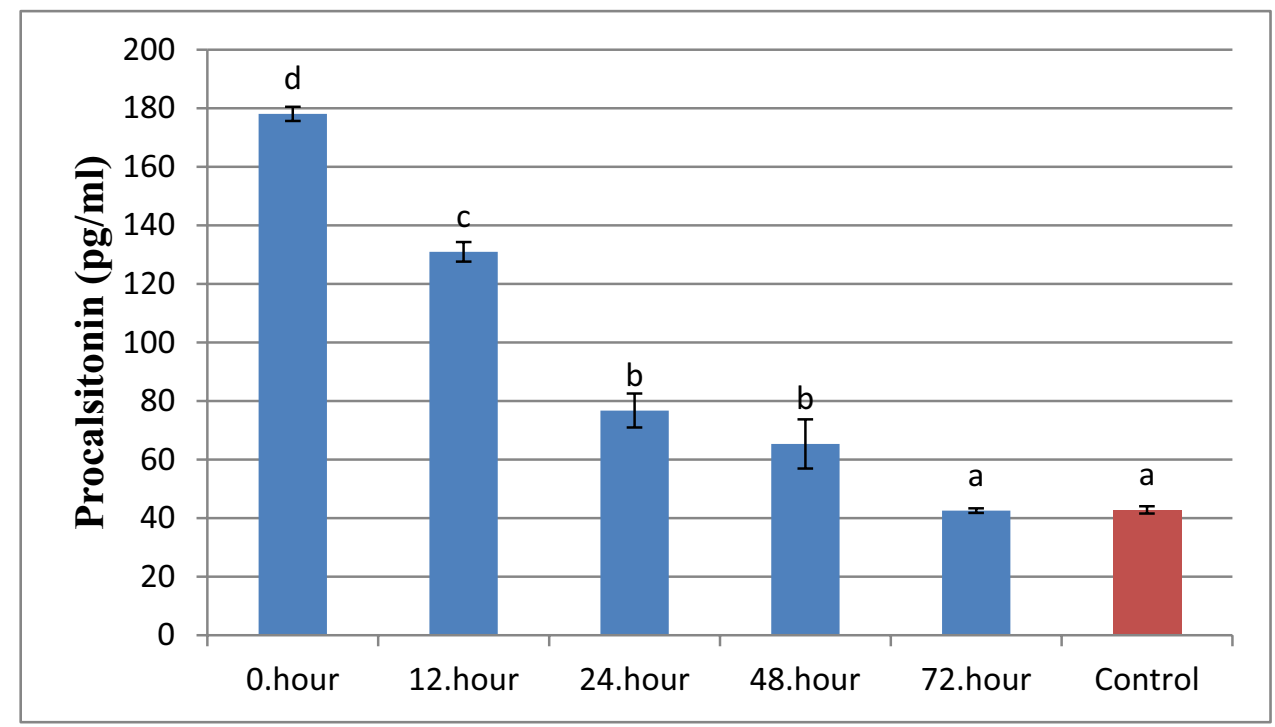


Fig. 2 The neopterin concentrations of the group with sepsis measured at different times and the neopterin concentration of the control group. ${ }^{\mathrm{a}-\mathrm{e}}$ indicates the statistical differences between the groups $(p<0.05)$

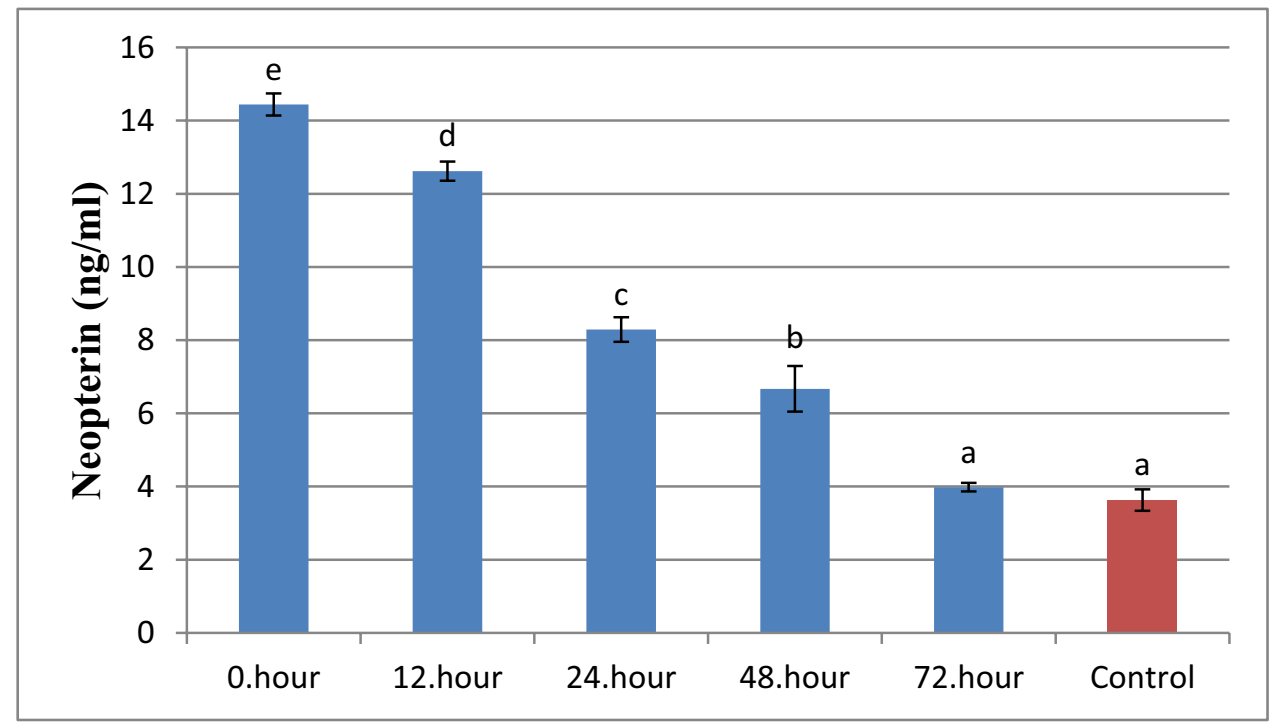

exposed to poor care and hygienic conditions, where four of them received no colostrum and seven partially received sufficient colostrum. Hypothermia or hyperthermia may develop in sepsis (Fecteau et al. 2009; Ylldiz et al. 2018). Also in our study, some calves had hypothermia and some had hyperthermia which caused the mean body temperature to appear within normal limits. Therefore, this study found no statistically significant difference between the calves in sepsis and control groups in terms of body temperature. Dehydration and SIRSinduced tachycardia may develop in animals with sepsis

Table 2 Correlation values of procalcitonin and neopterin with all parameters in the study

\begin{tabular}{lll}
\hline Parameters & Neopterin $(\mathrm{ng} / \mathrm{mL})$ & $\begin{array}{l}\text { Procalsitonin } \\
(\mathrm{pg} / \mathrm{mL})\end{array}$ \\
\hline Body temperature $\left({ }^{\circ} \mathrm{C}\right)$ & -0.129 & -0.171 \\
Heart beats/min & $0.465^{* *}$ & $0.504^{* *}$ \\
Breaths/min & $0.458^{* *}$ & $0.513^{* *}$ \\
Total leukocytes count $\left(\times 10^{3} / \mu \mathrm{L}\right)$ & -0.024 & -0.024 \\
Alanine aminotransferase $(\mathrm{IU} / \mathrm{L})$ & $0.288^{* *}$ & $0.330^{* *}$ \\
Aspartate aminotransferase (IU/L) & $0.218^{*}$ & $0.256^{*}$ \\
Gamma-glutamyl transferase (IU/L) & $0.428^{* *}$ & $0.455^{* *}$ \\
Alkaline phosphatase (IU/L) & $0.334^{* *}$ & $0.298^{* *}$ \\
Glucose $(\mathrm{mg} / \mathrm{dL})$ & -0.194 & $-0.233^{* *}$ \\
Creatinine $(\mathrm{mg} / \mathrm{dL})$ & $0.514^{* *}$ & $0.584^{* *}$ \\
Urea $(\mathrm{mg} / \mathrm{dL})$ & $0.256^{*}$ & $0.278^{* *}$ \\
Albumin $(\mathrm{g} / \mathrm{dL})$ & $-0.371^{* *}$ & $-0.423^{* *}$ \\
Kreatin Kinaz $(\mathrm{IU} / \mathrm{L})$ & $0.339^{* *}$ & $0.316^{* *}$ \\
Neopterin $(\mathrm{ng} / \mathrm{mL})$ & - & $0.935^{* *}$ \\
Procalsitonin $(\mathrm{pg} / \mathrm{mL})$ & $0.935^{* *}$ & - \\
\hline
\end{tabular}

*Correlation is significant at the 0.05 level

${ }^{* * *}$ Correlation is significant at the 0.01 level
(Fecteau et al. 2009; Naseri, 2017; Y1ldı et al. 2018). This study determined that the reason for tachycardia in animals with sepsis was due to dehydration and SIRS. Studies have reported that calves with sepsis have respiratory rates above normal levels (Ercan et al. 2016; Ylldiz et al. 2018). Tachypnea develops in sepsis and infectious cases due to compensation

Table 3 Neopterin and procalcitonin according to etiological agents and hours

\begin{tabular}{|c|c|c|c|c|c|}
\hline Hours & Parameters & Agents & $N$ & Mean \pm SEM & $p$ \\
\hline \multirow[t]{4}{*}{ Oth* } & \multirow[t]{2}{*}{ Neopterin (ng/mL) } & Viral agents & 8 & $14.76 \pm 0.58$ & \multirow[t]{2}{*}{0.181} \\
\hline & & E.coli & 7 & $14.13 \pm 0.31$ & \\
\hline & \multirow[t]{2}{*}{ Procalsitonin (pg/mL) } & Viral agents & 8 & $179.08 \pm 3.28$ & \multirow[t]{2}{*}{0.244} \\
\hline & & E.coli & 7 & $177.34 \pm 4.84$ & \\
\hline \multirow[t]{4}{*}{12 th } & \multirow[t]{2}{*}{ Neopterin (ng/mL) } & Viral agents & 8 & $12.68 \pm 0.40$ & \multirow[t]{2}{*}{0.423} \\
\hline & & E.coli & 7 & $12.54 \pm 0.36$ & \\
\hline & \multirow[t]{2}{*}{ Procalsitonin (pg/mL) } & Viral agents & 8 & $133.36 \pm 3.77$ & \multirow[t]{2}{*}{0.569} \\
\hline & & E.coli & 7 & $128.24 \pm 5.91$ & \\
\hline \multirow[t]{4}{*}{ 24th } & \multirow[t]{2}{*}{ Neopterin (ng/mL) } & Viral agents & 8 & $8.82 \pm 0.41$ & \multirow[t]{2}{*}{0.852} \\
\hline & & E.coli & 7 & $7.69 \pm 0.48$ & \\
\hline & \multirow[t]{2}{*}{ Procalsitonin (pg/mL) } & Viral agents & 8 & $82.10 \pm 10.22$ & \multirow[t]{2}{*}{0.126} \\
\hline & & E.coli & 7 & $70.66 \pm 4.26$ & \\
\hline \multirow[t]{4}{*}{ 48th } & \multirow[t]{2}{*}{ Neopterin (ng/mL) } & Viral agents & 8 & $7.40 \pm 1.13$ & \multirow[t]{2}{*}{0.121} \\
\hline & & E.coli & 7 & $5.83 \pm 0.18$ & \\
\hline & \multirow[t]{2}{*}{ Procalsitonin (pg/mL) } & Viral agents & 8 & $70.65 \pm 15.63$ & \multirow[t]{2}{*}{0.152} \\
\hline & & E.coli & 7 & $59.20 \pm 3.95$ & \\
\hline \multirow[t]{4}{*}{ 72th } & \multirow[t]{2}{*}{ Neopterin (ng/mL) } & Viral agents & 8 & $5.37 \pm 1.41$ & \multirow[t]{2}{*}{0.075} \\
\hline & & E.coli & 7 & $4.00 \pm 0.10$ & \\
\hline & \multirow[t]{2}{*}{ Procalsitonin $(\mathrm{pg} / \mathrm{mL})$} & Viral agents & 8 & $59.01 \pm 17.18$ & 30.071 \\
\hline & & E.coli & 7 & $43.29 \pm 1.43$ & \\
\hline
\end{tabular}

$S E M$ standard error of mean. No statistical difference was found in the comparison of etiological agents $(p>0.05)$. Viral agents: rotavirus and coronavirus. *Before treatment 
mechanisms (Fecteau et al. 1997, 2009; Naseri, 2017). Similarly, in our study, we think that tachypnea findings developed due to sepsis. Prolonged CRT in sepsis is a result of multiple organ dysfunction and its adverse effects on cardiovascular system (Fecteau et al. 2009). In consistent with those in the literature, in this study, prolonged CRT in calves with sepsis has been found. Leukocytosis and leukopenia can develop in calves with sepsis, and there may be no change in WBC of some cases (Dellinger et al. 2013; Naseri, 2017). This study determined a statistically significant difference between the WBC of calves in the sepsis and control groups, and found that four of calves with sepsis had leukopenia, five had leukocytosis, and six had WBC within reference values. These results are consistent with those in the literature. Hemostasis deteriorates in calves with diarrhea due to liquid electrolyte losses. In addition, carbohydrate stores are emptied and hypoglycemia table appears due to dehydration (Dratwa-Chałupnik et al. 2012). One study of calves with sepsis found lower serum glucose concentration in sepsis group than in healthy ones (Ercan et al. 2016). In consistent with these reports, this study also found lower blood glucose concentration in calves with sepsis than in healthy ones. Dehydration is the most important reason for increased serum urea and creatinine concentration in calves with diarrhea (Dratwa-Chałupnik et al. 2012). Ercan et al. (2016) conducted a study on calves with sepsis, and reported that calves with sepsis had higher serum creatinine concentration than healthy ones. In consistent with those in the literature, this study determined the reason for high concentration of serum urea and creatinine in calves with sepsis than in healthy ones as the decreased blood flow to kidneys. Increased serum urea and creatinine in animals with sepsis were considered a result of dehydration. The amount of serum albumin may decrease as a result of the destruction caused by infections and inflammation (Talkhan et al. 2009). This study suggests that decreased amount of albumin was because of both negative acute phase proteins and impaired liver function. This study has reported that the concentration of serum CK enzyme increases in sepsis patients due to the destruction of muscle tissue (Aydın et al. 2018). In consistent with this report, this study found higher concentration of serum CK enzyme in calves with sepsis than in healthy ones. This result may be because of muscle damage in bedridden calves with sepsis. Studies have reported increased serum ALT, AST, GGT, and ALP concentrations in neonatal calves with diarrhea symptoms (Başer and Civelek, 2013; Bozukluhan et al. 2017; Naseri, 2017). Similarly, this study found higher concentrations of serum ALT, AST, GG, and ALP in calves with sepsis than in healthy ones. Procalcitonin is accepted as an acute phase reactant rising especially in bacterial infections, which are considered to be specific for infection. In addition, constant high procalcitonin concentration in patients with sepsis is considered an indicator of poor prognosis. In general, procalcitonin does not increase in local infections, but rises in systemic infections such as sepsis; therefore, it is important for clinical follow-up (Hacımustafaoğlu, 2017). This may be because of impaired intestinal and liver functions due to sepsis. Different studies have reported increased serum procalcitonin concentrations in people, dogs, horses, and calves with sepsis (Yilmaz et al. 2008; Riedel, 2012; Rieger et al. 2014; Ercan et al. 2016; Bonelli et al. 2018; Kirbas et al. 2019). Köse et al. (2013) found quite higher concentrations of procalcitonin in a group with sepsis compared to those without sepsis. This study also found high levels of serum procalcitonin in sepsis group before the treatment. In addition, there was a significant decrease in serum procalcitonin concentration of calves with sepsis during the treatment. Therefore, procalcitonin was considered an important biomarker to evaluate the prognosis of sepsis. Neopterin levels may be useful to evaluate the prognosis of various pathological conditions and the activity of diseases (Eisenhut, 2013; Zuo et al. 2018; Ünüvar and Aslanhan, 2019). As the concentration of neopterin increases in patients with septic shock more than in those with systemic inflammatory response syndrome, it can be used in understanding whether the patient is in septic shock (Ruokonen et al. 2002; Sönmezer and Tülek, 2015). Ercan et al. (2016) found higher concentrations of serum neopterin in sepsis group than in healthy animals in their study on calves with sepsis. In consistent with those in the literature, this study found higher concentration of serum neopterin in calves with sepsis than in healthy ones. In addition, this study found significant decrease in serum neopterin concentrations of calves with sepsis measured at certain intervals during the treatment. Therefore, neopterin was considered an important biomarker to evaluate and diagnose sepsis in calves. This study determined a high positive correlation between neopterin and procalcitonin. Neopterin and procalcitonin concentrations were significantly higher at 0 th $\mathrm{h}$ in calves with sepsis than in healthy ones. Just as neopterin, procalcitonin concentration of calves with sepsis decreased along with the treatment, and approached to the concentration of those in the control group. This indicates that both procalcitonin and neopterin can be used to determine the treatment efficacy in calves with sepsis. In neonatal calves with sepsis, neopterin and procalcitonin concentrations were evaluated at certain times during treatment. The procalcitonin and neopterin, which were high before the treatment in the sepsis group, significantly decreased along with the treatment, suggesting that it may be important for the efficacy of the treatment. A high positive correlation between serum biochemical parameters, especially creatinine, neopterin, and procalcitonin concentrations, seems to be prognostically important. A significant correlation between neopterin and procalcitonin $(r=0.935, p<0.01)$ suggests that these parameters may be good indicators especially in sepsis calves and have prognostic significance in patient follow-up. A positive correlation between clinical improvement and biomarkers was determined by monitoring sepsis group for a certain period of time. In conclusion, this study will 
shed a light on few studies on biomarkers in the field of veterinary medicine and contribute to the literature. This study is important because it is one of the first studies in which neopterin and procalcitonin concentrations were monitored in neonatal sepsis calves at certain time intervals. There was a positive correlation between procalcitonin, neopterin, and serum biochemical parameters including AST, ALT, GGT, ALP, creatinine, and urea. However, there was a negative correlation between procalcitonin, neopterin with albumin. The reduction of neopterin and procalcitonin during treatment and the survival of calves were considered to be prognostically important.

\section{Conclusion}

As a result, some serum biochemical parameters increased due to sepsis-related organ damage. Both neopterin and procalcitonin concentrations decreased along with the treatment, confirming the presence of sepsis in calves and suggesting that sepsis could be a prognostic indicator. Therefore, both procalcitonin and neopterin can be prognostic and diagnostic in calves with sepsis.

Author contribution EA and GG planned and designed the research. EA followed the clinical process. EA made laboratory measurements. EA analyzed statistical data. EA and GG discussed the results and contributed to the final manuscript.

Funding This work is supported by the Kafkas University Scientific Research Projects Coordinator (Project No: 2018-TS-57).

\section{Declarations}

Ethics approval All institutional and national guidelines for the care and use of calves were followed.

Competing interests The authors declare no competing interests.

\section{References}

Akyüz, E., Coşkun, A. and Şen, İ., 2016. The effects of fluïd resuscitation on the hemodynamic parameters of experimental induced endotoxemia in the neonatal calves. Eurasian Journal of Veterinary Sciences, 32, 246-254.

Akyüz, E., Uzlu, E., Sezer, M., Kuru, M. and Gökce, G., 2019. Changes in calcium, phosphorus and magnesium concentratons in neonatal sepsis suspected calves. In:, 4th International Congress on Advances of Veterinary Sciences and Techniques (ICAVST), Kiev, Ukraine.

Aldridge, B.M., Garry, F.B. and Adams, R., 1993. Neonatal septicemia in calves: 25 cases (1985-1990). Journal of the American Veterinary Medical Association, 203, 1324-1329.

Aydın, Y., Senem Akdeniz, Y., Çakmak, F., İpekci, A., Kıyak, S.K., Öztürk, M. and İkizceli, İ., 2018. Analysis of the patients with elevated creatinine kinase (CK) level at emergency department. Journal of Anatolian Medical Research, 3, 1-24.

Aydogdu, U. and Guzelbektes, H., 2018. Effect of colostrum composition on passive calf immunity in primiparous and multiparous dairy cows. Veterinarni Medicina, 63, 1-11.

Başer, D. and Civelek, T., 2013. Correlations between venous acidbase status and renal function in neonatal calves with acute diarrhea. Kocatepe Veterinary Journal, 6, 25-31.

Basoglu, A., Sen, I., Meoni, G., Tenori, L. and Naseri, A., 2018. NMR-based plasma metabolomics at set intervals in newborn dairy calves with severe sepsis. Mediators of Inflammation, Article ID: 8016510.

Beydilli, Y. and Gökçe, H., 2019. Investigation of some hematolojic and biachemical parameters in neonatal calves with sepsis. Mehmet Akif Ersoy University Journal of Health Sciences Institute, 55-67.

Bonelli, F., Meucci, V., Divers, T.J., Boccardo, A., Pravettoni, D., Meylan, M., Belloli, A.G. and Sgorbini, M., 2018. Plasma procalcitonin concentration in healthy calves and those with septic systemic inflammatory response syndrome. The Veterinary Journal, 234, 61-65.

Bozukluhan, K., Merhan, O., Gokce, H.I., Deveci, H.A., Gokce, G., Ogun, M. and Marasli, S., 2017. Alterations in lipid profile in neonatal calves affected by diarrhea. Veterinary World, 10, 786-789.

Chatre, L., Verdonk, F., Rocheteau, P., Crochemore, C., Chrétien, F. and Ricchetti, M., 2017. A novel paradigm links mitochondrial dysfunction with muscle stem cell impairment in sepsis. Biochimica et Biophysica Acta - Molecular Basis of Disease, 1863, 2546-2553.

Chivate, C.G., Belwalkar, G.J., Limaye, R.P. and Patil, R. V, 2016. Procalcitonin as a marker for the diagnosis of sepsis. International Journal of Research in Medical Sciences, 4, 1216-1218.

Çitil, M. and Gökçe, E., 2013. Neonatal septicemia. Turkiye Klinikleri Journal of Veterinary Sciences, 4, 62-70.

Constable, P., 2007. A textbook of the diseases of cattle, horses, sheep, pigs and goats, O. Radostits, C. Gay, K. Hinchcliff , and P. Constable (eds), 10th edition, Saunders, Philadelphia.

Dellinger, R.P., Levy, M.M., Rhodes, A., Annane, D., Gerlach, H., Opal, S.M., Sevransky, J.E., Sprung, C.L., Douglas, I.S., Jaeschke, R., Osborn, T.M., Nunnally, M.E., Townsend, S.R., Reinhart, K., Kleinpell, R.M., Angus, D.C., Deutschman, C.S., Machado, F.R., Rubenfeld, G.D., Webb, S., Beale, R.J., Vincent, J.L., Moreno, R., Aitken, L., Al Rahma, H., Bernard, G.R., Biban, P., Bion, J.F., Calandra, T., Carcillo, J.A., Clemmer, T.P., Divatia, J. V., Du, B., Fujishima, S., Gando, S., Bruch, C.G., Guyatt, G., Hazelzet, J.A., Hirasawa, H., Hollenberg, S.M., Jacobi, J., Jenkins, I., Jimenez, E., Jones, A.E., Kacmarek, R.M., Kern, W., Koh, S.O., Kotani, J., Levy, M., Machado, F., Marini, J., Marshall, J.C., Masur, H., Mehta, S., Muscedere, J., Napolitano, L.M., Parker, M.M., Parrrillo, J.E., Qiu, H., Randolph, A.G., Rello, J., Resende, E., Rivers, E.P., Schorr, C.A., Shukri, K., Silva, E., Soth, M.D., Thompson, A.E., Vender, J.S., Webb, S.A., Welte, T. and Zimmerman, J.L., 2013. Surviving sepsis campaign: International guidelines for management of severe sepsis and septic shock. Intensive Care Medicine, 39, 165-228.

Dratwa-Chałupnik, A., Herosimczyk, A., Lepczynśki, A. and Skrzypczak, W.F., 2012. Calves with diarrhea and a water-electrolyte balance. Medycyna Weterynaryjna, 68, 5-8.

Eisenhut, M., 2013. Neopterin in diagnosis and monitoring of infectious diseases. Journal of Biomarkers, 2013, 1-10.

Ercan, N., Tuzcu, N., Başbug, O., Tuzcu, M. and Alim, A., 2016. Diagnostic value of serum procalcitonin, neopterin, and gamma interferon in neonatal calves with septicemic colibacillosis. Journal of Veterinary Diagnostic Investigation, 28, 180-183. 
Erkiliç, E.E., Merhan, O., Kirmizigül, A.H., Öğün, M., Akyüz, E. and Çitil, M., 2019. Salivary and serum levels of serum amyloid A, haptoglobin, ceruloplasmin and albumin in neonatal calves with diarrhoea. Kafkas Universitesi Veteriner Fakültesi Dergisi, 25, 583-586.

Fecteau, G., Paré, J., Van Metre, D.C., Smith, B.P., Holmberg, C.A., Guterbock, W. and Jang, S., 1997. Use of a clinical sepsis score for predicting bacteremia in neonatal dairy calves on a calf rearing farm. Canadian Veterinary Journal, 38, 101-104.

Fecteau, G., Smith, B.P. and George, L.W., 2009. Septicemia and Meningitis in the Newborn Calf. Veterinary Clinics of North America - Food Animal Practice, 25, 195-208.

Hacımustafaoğlu, M., 2017. Procalcitonin as a acute phase reactant. Journal of Pediatric Infection, 11, 196-197.

House, J., Smith, G., McGuirk, S., Gunn, A. and Izzo, M., 2015. Large Animal Internal Medicine, 5th Edition, Manifestations and management of disease in neonatal ruminants. B. Smith (ed), 30th April 2014: St. Louis, USA).

Kirbas, A., Kandemir, FM., Celebi, D., Hanedan, B., Timurkan, MO., 2019. The use of inflammatory markers as a diagnostic and prognostic approach in neonatal calves with septicaemia. Acta Veterinaria Hungarica, 67(3): 360-376.

Köse, B., Özcan, N., Kaymak, Ç., Başar, H., Kotanoğlu, M., Özcan, A., Baltac1, B., 2013. Assessment of scoring systems, procalcitonin levels and blood gas parameters used in follow up of septic and non-septic patients. Türkiye Klinikleri Anesteziyoloji Reanimasyon Dergisi, 11(3), 137-42

Kozłowska-Murawska, J. and Obuchowicz, A.K., 2008. Clinical usefulness of neopterin. Wiadomości lekarskie, 61, 269-272.

Lorenz, I., Fagan, J. and More, S.J., 2011. Calf health from birth to weaning. II. Management of diarrhoea in pre-weaned calves. Irish Veterinary Journal, 64, 9.

Maden, M. and Köse, S.I., 2013. Biomarkers and clinical usages. The Journal of Faculty of Veterinary Medicine, Dicle University, 2, 1-8.

Matur, E., Eraslan, E. and Çötelioğlu, Ü., 2017. Biology of procalcitonin and its potential role in veterinary medicine. Journal of Istanbul Veterinary Sciences, 1, 16-27.

Michalak, Ł., Bulska, M., Strząbała, K. and Szcześniak, P., 2017. Neopterin as a marker of cellular immunological response. Postepy higieny i medycyny doswiadczalnej (Online), 71, 727-736.

Moore, R.E., Kirwan, J., Doherty, M.K. and Whitfield, P.D., 2007. Biomarker discovery in animal health and disease: The application of post-genomic technologies. Biomarker Insights, SAGE Journals, doi: https://doi.org/10.1177/117727190700200040.

Naseri, A., 2017. Echocardiographic assesment of left ventriculer systolic function in calves with naturally occurring severe sepsis and septic shock and changes in these functions related to applied treatment; longitudinal study. Selçuk University, Health Sciences Institute, Konya, Turkey.

Ok, M., Güler, L., Turgut, K., Ok, Ü., Şen, I., Gündüz, I.K., Birdane, M.F. and Güzelbekteş, H., 2009. The studies on the aetiology of diarrhoea in neonatal calves and determination of virulence gene markers of Escherichia coli strains by multiplex PCR. Zoonoses and Public Health, 56, 94-101.
Pergialiotis, V., Karampetsou, N., Zoumpourlis, P., Papantoniou, N., Thomakos, N. and Daskalakis, G., 2018. Serum neopterin levels in women with preeclampsia: a systematic review. Hypertension in Pregnancy, 37, 220-226.

Riedel, S., 2012. Procalcitonin and the role of biomarkers in the diagnosis and management of sepsis. Diagnostic Microbiology and Infectious Disease, 73, 221-227.

Rieger, M., Kochleus, C., Teschner, D., Rascher, D., Barton, A.K., Geerlof, A., Kremmer, E., Schmid, M., Hartmann, A. and Gehlen, H., 2014. A new ELISA for the quantification of equine procalcitonin in plasma as potential inflammation biomarker in horses. Analytical and Bioanalytical Chemistry, 406, 5507-5512.

Ruokonen, E., Ilkka, L., Niskanen, M. and Takala, J., 2002. Procalcitonin and neopterin as indicators of infection in critically ill patients. Acta Anaesthesiologica Scandinavica, 46, 398-404.

Sen, I. and Constable, P., 2013. General overview to treatment of strong ion (metabolic) acidosis in neonatal calves with diarrhea. Eurasian Journal of Veterinary Science, 29, 114-120.

Sönmezer, M.Ç. and Tülek, N., 2015. Biomarkers in bacterial infections and sepsis. Klimik Journal, 28, 96-102.

Talkhan, O.F.A., Salama, S.E.M., Kholy, M.M.E., Mosallam, S.A. and Atwa, E.I., 2009. Bacterial agent of respiratory manifestation in cattle and associated biochemical alterations in Menoufiea Governorate. Nature and Science, 7, 26-30.

Trefz, F.M., Lorch, A., Feist, M., Sauter-Louis, C. and Lorenz, I., 2013. The prevalence and clinical relevance of hyperkalaemia in calves with neonatal diarrhoea. The Veterinary Journal, 195, 350-356.

Tyler, J.W., Hancock, D.D., Thorne, J.G., Gay, C.C. and Gay, J.M., 1999. Partitioning the mortality risk associated with inadequate passive transfer of colostral immunoglobulins in dairy calves. Journal of Veterinary Internal Medicine, 13, 335.

Ünüvar, S. and Aslanhan, H., 2019. Clinical significance of increased serum neopterin in chronic kidney failure as a biomarker of cellmediated immunity. Journal of Medical Biochemistry, 38, 1-5.

Yildiz, R., Beslek, M., Beydilli, Y., Özçelik M, M. and Biçici, Ö., 2018. Evaluation of platelet activating factor in neonatal calves with sepsis. Journal of Turkish Veterinary Medical Society, 89, 66-73.

Yilmaz, Z., Ilcol, Y.O. and Ulus, I.H., 2008. Endotoxin increases plasma leptin and ghrelin levels in dogs. Critical Care Medicine, $36,828-833$

Zuo, H., Nygård, O., Ueland, P.M., Vollset, S.E., Svingen, G.F.T., Pedersen, E.R., Midttun, Meyer, K., Nordrehaug, J.E., Nilsen, D.W.T. and Tell, G.S., 2018. Association of plasma neopterin with risk of an inpatient hospital diagnosis of atrial fibrillation: Results from two prospective cohort studies. Journal of Internal Medicine, 283, 578-587.

Publisher's Note Springer Nature remains neutral with regard to jurisdictional claims in published maps and institutional affiliations. 